\title{
Thorstein Veblen, Bard of Democracy
}

\section{Trygve Throntveit}

\section{(2) OpenEdition}

\section{Journals}

Electronic version

URL: http://journals.openedition.org/ejpap/2281

DOI: 10.4000/ejpap.2281

ISSN: 2036-4091

\section{Publisher}

Associazione Pragma

Electronic reference

Trygve Throntveit, "Thorstein Veblen, Bard of Democracy", European Journal of Pragmatism and American Philosophy [Online], XIII-1 | 2021, Online since 02 April 2021, connection on 04 April 2021. URL: http://journals.openedition.org/ejpap/2281 ; DOI: https://doi.org/10.4000/ejpap.2281

This text was automatically generated on 4 April 2021.

\section{(2) $\oplus \Theta \Theta$}

Author retains copyright and grants the European Journal of Pragmatism and American Philosophy right of first publication with the work simultaneously licensed under a Creative Commons AttributionNonCommercial-NoDerivatives 4.0 International License. 


\title{
Thorstein Veblen, Bard of Democracy
}

\author{
Trygve Throntveit
}

Intellectual history is often an exercise in irony. Sometimes the most influential or generative ideas in a field of endeavour come from those least congenial to the work itself - or seemingly so. Such is the case with Thorstein Veblen (1857-1929) and the import of his writings for the nebulous field of social aesthetics. Few remember Veblen as a connoisseur of beauty or champion of beauty's importance to an institutionally modern and technologically sophisticated society. Similarly few credit Veblen with any constructive theory of politics. ${ }^{1}$ Yet Veblen's conception of the beautiful, his account of its role in human cultural evolution, and his critique of its perversion in the industrialized societies of the nineteenth and early twentieth centuries are invaluable to contemporary social-aesthetic aims of political and economic reconstruction.

Indeed, in contrast to the Veblen of memory, the real Veblen devoted significant intellectual energy to building a theory of what political thinkers today call public work: creative, negotiated, open-ended production of shared goods by individuals alert both to self-interest and collective needs. ${ }^{2}$ Despite his widespread characterization as an intellectual outsider, moreover, Veblen's public-work aesthetics partakes of the rich tradition of philosophical pragmatism and points to its continuing value for contemporary aesthetic, social, and political theory. ${ }^{3}$ The so-called "bard of savagery" was not repulsed by the pragmatists' modernist fusion of meaning with utility, but stimulated by their generous interpretation of what "utility" can mean. Indeed, the most relevant of Veblen's insights for modern democrats reflect psychological assumptions derived from William James and a vision of a good society - and how to achieve it - congruent with John Dewey's. ${ }^{4}$

In sum, Veblen is better understood as a "bard of democracy," narrating the travails and affirming the ideals of a culture aspiring to self-government. Augmented by recent advances in cultural evolutionary theory as well as public work philosophy, Veblen's insights suggest a vision of democratic citizenship defined by cooperative imagination, production, critique, and re-creation of a moral and material commonwealth. Given the 
failures of the liberal and statist paradigms that still dominate the political imagination, it is a vision that might lend the fragmented field of social aesthetics a common, compelling narrative of its own.

\section{Reconsidering Veblen}

4 Veblen has long been famous primarily as a critic of the assumptions, claims, and practices undergirding the social order of industrialized democracies (in his day and ours): a social order that, he argued, rewards the wasteful behaviors of the powerful and exploits the productive efforts of the weak. ${ }^{5}$ To be sure, intellectual and economic historians recognize his seminal contributions to the field of "institutional economics," emphasizing the historically contingent nature of economic phenomena rather than identifying transhistorical laws that, by logical necessity, support the status quo. ${ }^{6}$ Rarely, however, have scholars appreciated Veblen's efforts to explain and guide us through the psychosocial world he thought too many economists ignored.

5 For decades, the reigning interpretation was that of Theodore Adorno, who in 1941 decried Veblen's "attack on culture" as a particularly grotesque excrescence of a malignant "American pragmatism." Founded in a theory of truth as "usefulness for the societal whole," Veblen's critique, Adorno charged, left no room for the pursuit of beauty, individual ennoblement, or genuine solidarity with other humans as ends in themselves. ${ }^{7}$ Rick Tilman was among the first to turn Adorno's interpretations of Veblen and pragmatism on their heads. Tilman placed Veblen and Dewey among the vanguard of an American "social aesthetics," due to their calls for empowering common people to recognize and propagate values promoting the general welfare over vested interests. Yet even while noting strong congruencies between Veblen's institutionalism and Dewey's pragmatism, Tilman identified no direct line of influence between the two thinkers. He also downplayed Veblen's interest in an explicit, constructive effort at "democratizing" America's "elitist" culture like that which occupied much of Dewey's career. ${ }^{8}$

6 Only in the late 2000s did research clarify Veblen's relationship to pragmatism and its role in his contributions to aesthetic and social theory. That research revealed Veblen's direct debt to Dewey's friend and fellow pragmatist, William James, while also drawing a direct line linking Veblen's pragmatist account of human psychology to a coherent aesthetic theory and an explicit project of democratic renewal. On this account, Veblen was neither philistine nor functionalist. Rather, he believed that all judgment originated in an impulse to imbue sense perceptions with thematic unity; that this aesthetic impulse was responsible for advancing human knowledge; and that the most beautiful objects, actions, or ideas met a standard of communal benefit reflecting humanity's naturally selected awareness of social interdependence. In short, the beautiful, for Veblen, was what helped to unify human individuals into humane communities, equipped and determined to advance their mutual physical, psychological, and spiritual well-being. ${ }^{9}$

7 So, what did this conception of "beauty" look like in finer detail? How did Veblen come to hold it? And what does it promise for the field of social aesthetics? 


\section{The Beauty of Veblen's Aesthetics}

8 Veblen's first fruitful encounter with aesthetic theory was through his reading of Immanuel Kant and, most likely, Friedrich Schiller. From his idiosyncratic reading of Kant's "Critique of Judgement," Veblen gleaned the notion that the human mind, upon encountering unfamiliar phenomena, initially responds according to a "principle of adaptation," imagining a reconciliation of old and new experience in which both are thematically linked to the other as well as to broader mental themes. The immediate "results" of this aesthetic "induction," as Veblen called it, are of varying and uncertain importance: they "guide us in guessing about the given data, and then leave it to experience to credit or discredit our guesses." The ongoing process of aesthetic induction, however, is critical to moral freedom and intellectual creativity. For Veblen, the personal freedom to order our experience, paired with thought's "unavoidable determination" by the limits of that same experience, demonstrates both the practicability of moral action in the external world and the origin of such action in the "aesthetic stage" of judgment - the stage which also makes translation of raw perceptions into coherent knowledge possible. ${ }^{10}$

Evidence of Veblen's debt to Schiller is more circumstantial, but repays consideration. Central to Veblen's mature aesthetics was his theory that the mind's directed efforts to interpret new experience in terms of old are joined by an "idle response" to stimulus, or what he more frequently termed "idle curiosity": a meandering exploration of possible relations between phenomena, generating novel hypotheses about experience that broaden the mind's creative, knowledge-producing scope. Veblen described idle curiosity as "closely related to the aptitude for play, observed both in man and in the lower animals" - a description, as Alan W. Dyer has argued, evoking Schiller's notion of "play" as the quintessential aesthetic experience, combining our impulse to surrender to the sensory world with our impulse to unify it intellectually. ${ }^{11}$ Like Schiller, Veblen insisted that the conclusions of such playful investigations are neither solely "contingent" upon the environment nor wholly "compelled" by reason. Rather, Veblen argued, idle curiosity seeks "dramatic consistency" in experience, favoring knowledge relations that imbue phenomena with an anthropomorphic purpose, or "life-history," to which we can relate our own purposes and experience. ${ }^{12}$

Veblen's developing economic, sociological, and political concerns ultimately demanded more from aesthetic theory than the German tradition could give. By 1891, Veblen had concluded that modern economic conditions habituated individuals to value all things by criteria elevating costliness over other qualities, beauty included - a development he blamed for the social and political unrest affecting those unable to spend as the wealthy could spend..$^{13}$ Under such conditions the Germans failed him. Kant, despite Veblen's early interpretation of his writings, denied that aesthetic values yield insights into moral truth or practical conduct. Meanwhile, Schiller's talk of an "ideal state" in which all are free to engage in play ignored the impediments to its realization so long as time and space for leisure remained expensive commodities, available to the few. And although the towering figure of German philosophy in Veblen's day, Georg Friedrich Hegel, endorsed aesthetic education as one (comparatively unimportant) motor of freedom's apotheosis in a rationally structured state, by the 1880s Hegel's larger philosophical system had become the semi-official 
apologetic for the German "dynastic state" that Veblen judged the epitome of predatory wealth. ${ }^{14}$

11 Thus from 1890 onward political economy became Veblen's primary focus. Yet embedded in his critique of neoclassical economic orthodoxy there remained an aesthetic critique of the predatory, wasteful, ugly culture he thought it reflected and bolstered. One major thrust of his attack, aimed at the excessive formalism of neoclassical economics, was inspired by Darwin's evolutionism: Veblen thought Darwin's work revealed science itself as evolutionary, generating "transitional" truths rather than discovering immutable laws such as those averred by many economists. ${ }^{15}$ The specific grounds of Veblen's critique, however, rested on psychological arguments not directly traceable to Darwin. Veblen denied economists' prevailing "associationist" account of the mind as wholly shaped by the impinging environment, insisting rather that the mind "seeks realisation and expression through unfolding activity." He also rejected the conventional "hedonistic" view of the mind as a "lightning calculator" of pain and pleasure, stressing instead the social and spiritual character of humans' "desire to think that their life is of some use" - a "norm of economic merit," certainly, but one related to "the ethical norm of conduct, on the one hand, and the aesthetic norm of taste, on the other." 16

12 This emerging complex of economic, ethical, and aesthetic claims owed its psychological foundations to William James. Sparse but significant markings in Veblen's copy of James's Principles of Psychology (1890), combined with citations in Veblen's own works, demonstrate that he read James's Principles sometime between 1896 and $1906 .{ }^{17}$ The passages marked and cited suggest that James made three important contributions to Veblen's social aesthetics. First, James helped Veblen formulate his account of the mind as active: creating knowledge rather than passively receiving it from the environment. Second, Veblen cited James's work to support his claim that knowledge creation began with "idle curiosity," the playful impulse to imbue experience with thematic unity. Finally, Veblen drew on James's psychology of instincts and habits to argue that the mind naturally valued social unity above all, judging the beauty of objects and ideas by their perceived potential to advance it - a perception, however, that was influenced by other instincts, and filtered through the widespread habits of thinking that Veblen would label institutions.

Veblen did not explicitly identify his account of the mind with pragmatist epistemology until 1906. As early as 1898 , however, Veblen was deploying the arguments of James's functionalist psychology against the associationist theory of Herbert Spencer and his followers among economists and sociologists. In that year, Veblen argued that while humans obviously responded to environmental stimuli, they were also endowed "by selective necessity" with "a proclivity for purposeful action" - a talent for manipulating their environment that was their supreme advantage over other species. ${ }^{18}$ Here Veblen replaced the simple assertion of mental predispositions made in his article on Kant with an explication of their evolutionary origins and interactive function in and with the environment that directly echoed James. Though he cited no source, Veblen's copy of Principles contains marginalia interrogating James's arguments for the biological basis of volitional thought. ${ }^{19}$ Moreover, the psychological doctrines Veblen endorsed in 1898 were exactly those he affirmed in his 1906 article "The Place of Science in Modern Civilization," where he did explicitly credit them to pragmatist 
epistemology: "Current psychology is nearly at one in saying that all learning is of a 'pragmatic' character." 20

14 aesthetic criteria played in advancing knowledge. In "Science in Modern Civilization" Veblen argued that the mind's "naïve pragmatism" - his term for thought directed toward a proximate, technical end - had evolved from another, now complementary process which did not create knowledge for immediate use, but merely explored aesthetically satisfying relations among phenomena: the process of "idle curiosity." ${ }^{21}$ Whether or not Schiller sparked this idea for Veblen, it was James who helped him elaborate it. Citing James's Principles as authority, Veblen claimed that the idly curious tendency to gather all experience, useful or not, under one thematic umbrella had over millennia created "a more and more comprehensive system of knowledge" that eventually engendered modern science. ${ }^{22} \mathrm{James}$ had argued that as imagined relations between objects of thought were found congruent with the "time- and space-relations" we encounter in experience, their scientific value came to obscure their original aesthetic character. Similarly, Veblen argued that as societies advanced, the drive to find consistency among rapidly multiplying facts demanded ever-closer analyses of experience, under which the "dramatization of phenomena" assumed a "less personal" cast. But never, he insisted, did cognition "lose its dramatic character." 23 playful and aesthetic in origin hardly jibes with popular portraits of Veblen the austere materialist. But neither should it obscure Veblen's strong association of beauty and practical utility. Instead, it suggests that there is some cognitive process by which beauty and utility are reconciled - and that is just what Veblen provided. The central argument of Veblen's aesthetics was that human activity is largely driven by an "instinct of workmanship" judging both the beauty and practical value of an object or idea in public terms: that is, according to the benefits it promised to the society upon which the individual depends for secure and meaningful existence. ${ }^{24}$

Veblen considered this instinct of workmanship both an anthropological fact and a normative standard that, if widely and wisely applied, could facilitate the democratic renewal of society. But how did the instinct evolve, and what would its disciplined, fruitful application look like? "It may be in place to recall the modern psychological position," Veblen wrote in his most famous work, The Theory of the Leisure Class (1899). "Beauty of form seems to be a question of facility of apperception," meaning "the mind readily unfolds its apperceptive activity in the directions which the object in question affords." Veblen clarified this obscure statement by translating it into evolutionary terms. The sense of beauty, he argued, illustrates the mind's "selective adaptation" to the "savage" state characterizing humankind's long prehistory, during which the search for the useful in experience became essential to mental structure in ways other habits of thought were not. "Facility of apperception," then, meant the ease with which the mind imagines a relationship between itself and the object perceived - a relationship that might be exploited to enhance survival. ${ }^{25}$

In essence, Veblen had reformulated "aesthetic induction" as an adaptive trait, with origins in the cerebral "plasticity" James hypothesized in Principles. Moreover, Veblen concluded that millennia of attraction to and use of certain objects with easily imagined purposes had influenced psychological and physical evolution both, so that beauty and potential for physical manipulation were often indistinct. Yet beauty was

European Journal of Pragmatism and American Philosophy, XIII-1 | 2021 
not simply a measure of material utility: "So far as the economic interest enters into the constitution of beauty," Veblen wrote, it is as "a manifest and readily inferable subservience to the life process," a process comprehending the gamut of desires - the "fullness of life." ${ }^{26}$ And while fullness of life includes "the fullness of life of the individual," that individual is fundamentally social: one member of a species whose initial biological and cultural development fostered an instinctive group solidarity breeding "sympathy with all facility of human life." 27

The beauty of this workmanlike aesthetics is that it is relevant to so many practical and intertwined problems of ethics, politics, and economics, yet does not reduce all aesthetic experience - and thus all human life - to ethical, political, or economic calculation. Veblen thought it obvious that some objects have an "intrinsic beauty" irreducible to any social transaction they might facilitate or technical advantage they might confer. Gold, he argued, had a "high degree of sensuous beauty," as did many gems, materials used for clothing, and landscapes. He even admitted that "most of the highly prized works of art are intrinsically beautiful, though with material qualification." ${ }^{28}$

The problem with this aesthetic philosophy, however, is just that matter of "material qualification." How do Veblen's claims about humans' social-aesthetic nature - their innate impulse to find beauty in whatever facilitates group thriving - jibe with the rise of the "leisure class," and specifically the "canon of waste" he identified as the governing principle of modern culture? How had appreciation for efficiency produced "habits of thought" under which expense determined beauty, personal consumption signified social worth, and the instinct for "generic usefulness" was stifled or subsumed by a "conventional antipathy to useful effort"? ${ }^{29}$

\section{A Comedy of Cultural Errors}

Veblen was aware of this problem. To explain how purpose, beauty, and truth were sundered, and to explore how utilitarian technique and aimless creativity might be resynthesized in gratifying action, were the primary goals of his aesthetic project. Critical to that project was the third psychological principle Veblen adopted from James: the idea that a dialectic of instinct and habit conditioned all human activity. As Veblen wrote in 1914, instincts dictated no "determinate sequence of action," but opened a "field for adaptation" to circumstances, and this interaction of instinct with environment often produced individual and collective habits. Habits, in turn, could replicate across time and culture and calcify into self-reinforcing "institutions," so illadapted to changed circumstances as to divert instinctual responses into channels that initially satisfied but ultimately frustrated the instincts themselves..$^{30}$ The idea that certain institutions had survived the "barbarian" stages of socio-political development to pervert our instinct of workmanship in modern times became the crux of Veblen's social critique. But Veblen did not despair of a happy response to these tragic errors of our cultural evolution: Institutions made by humans could be unmade by them as well.

Veblen first articulated his instinct-habit psychology in a series of articles from 1898, which became raw material for the work containing his most extended discussion of aesthetics, The Theory of the Leisure Class. Along with advancing a theory of the active mind anticipating his later, explicitly "pragmatic" rejection of Spencerian psychology, these articles adopted an instinct-psychology strongly resembling the one James 
articulated in chapters of Principles which Veblen read and cited in later works. ${ }^{31}$ James, for instance, argued that one species-generic instinct could engender another over evolutionary time, if memory induced a habitual response conferring advantage on those whose brains, due to "accidental variation," most easily developed or adopted a novel practice. Similarly, Veblen claimed in Leisure Class that "selective adaptation of men's habits of thought" could result in inherited impulses - the latter, of course, subject to pressure from other mechanisms, cultural as well as genetic. ${ }^{32}$

This account of humanity's simultaneously determined and self-made character is central to Veblen's political project and places him squarely within the pragmatist camp. Granted, Veblen disparaged the naïve pragmatism that made "thrift, prudence, equanimity, and shrewd management" the cardinal virtues of modern industrial life. ${ }^{33}$ Yet in a note preceding this apparent critique, Veblen explained that "pragmatism," as defined by its major exponents, included both naïve pragmatism and the idle curiosity that fostered innovation. ${ }^{34}$ Regardless of these inconsistencies, Veblen's writings are entirely congruent with the mission of pragmatism as James and Dewey conceived it: to repair the breach between intellectual and practical life in modern society, and protest what James called the "irremediable flatness" of experience it caused. Veblen, too, believed that social progress must lay somewhere between the "accentuated pragmatism" that defined all human purpose in material terms and the "pure science" that feigned detachment from any subjective purpose; neither could satisfy our implacable impulse to reconcile the "good and beautiful" with the "true." ${ }^{35}$ Veblen's social aesthetics was his effort to chart that middle course.

It was a project both normative and, in Veblen's view, empirical: Like James's and Dewey's efforts, Veblen's via media to the future reflected his surveys of the human past. ${ }^{36} \mathrm{He}$ argued that in Western society, the instinct of workmanship had been diverted into bizarre channels by habits propagated across social space and time, and now entrenched in the institution of "ownership." Workmanship was an evolved "taste for effective work" seeking to "further the life of the group"; ownership was a cultural convention - an institution - under which labor was distasteful, yet consuming its products honorable. ${ }^{37}$ At the root of invidious waste was, ironically, a touchstone of human sociability: the "proclivity to emulation" - a proclivity Veblen encountered in James's Principles..$^{38}$ Unlike the related instinct of "imitation," James wrote, "emulation" had "little connection with sympathy, but rather more with pugnacity" - that is, with demonstrating our value to the group vis-à-vis the value of others. ${ }^{39}$ Veblen's analysis of the interplay between the emulative and pugnacious instincts, and the interplay of both with social experience, proceeded similarly. While imitation in a culture of solidarity encouraged pursuit of the generically useful, increasing contact and competition with other human groups encouraged pugnacity, eventually making seizure of booty in war symbolic of one's tribal value. Emulation of these habits spawned the institution of ownership, which in turn bred other habits diverting the instinct of workmanship toward "predatory" efficiency - habits persisting long after technology obviated the struggle for subsistence that produced them. This instincthabit dialectic occurred, Veblen hypothesized, during the cultural evolutionary transition from small-group, peaceable "savagery" to the stratified, predatory "barbarism" of which modern Western civilization was a sophisticated elaboration. ${ }^{40}$

Veblen admitted that "appropriation of useful articles" was an instinct itself. But "ownership" Veblen defined as appropriation involving or symbolizing exploitation of 
people. Its earliest form, he wrote, was "ownership of the women by the able-bodied men of the community," originating in the kidnapping of females from other groups. This practice both reflected and fostered the barbarian's tendency to divide the world between the animate and inanimate, and to designate the bending of animate phenomena to one's own purposes ("exploit") as men's work, and the tedious manipulation of inanimate objects ("industry") as women's work. Through this cultural evolutionary feedback loop, "exploits" such as hunting animals and subduing other tribes became honorific, while "industry" became associated with drudgery and subservience. Yet appropriating the fruits of industry indicated prowess over their creators; thus the more goods appropriated, the more powerful one seemed. ${ }^{41}$

Evident prowess, then, was the end served by ownership and waste, and these habits warped judgments of beauty. "Habits of thought with respect to the expression of life in any given direction unavoidably affect the habitual view of what is good and right in life in other directions," Veblen wrote. "So the canon of honorific waste may, immediately or remotely, influence the sense of duty, [and] the sense of beauty." Intrinsically beautiful substances like gold became prized for public display as much as personal appreciation. The result for human-produced goods was that "marks of superfluous costliness" were valued as highly efficient signs of excess wealth accrued through predation, while goods were "humilific, and therefore unattractive," when demonstrating "too thrifty an adaptation to the mechanical end sought." The canon of waste not only turned intrinsically beautiful objects into symbols of exploitative prowess, but obscured the ancient correlation between beauty and efficiency. Judged by "the resulting standard of serviceability," Veblen concluded, a beautiful but nonwasteful article would "never pass muster." ${ }^{42}$ Humans still perceived and desired beauty in objects and ideas, especially those promising benefits to the collectives that sustained them. Their perceptions of beauty and benefit, however, were influenced by canons of judgment in overlapping spheres, products of centuries of invidious comparison under a predatory social order encouraging waste. A correspondingly pecuniary "schedule of aesthetic properties" was the result. ${ }^{43}$

Yet Veblen's historicist critique of taste also allowed for a different, more economically and spiritually serviceable schedule to emerge - under the right conditions. Veblen believed individuals, if encouraged to reflect upon the contingent and conflicting character of many of their tastes, could learn to discriminate between them, and find an aesthetic test to replace the canon of waste. Veblen thought that test should be our instinct of workmanship - our sense for the usefulness of objects, ideas, and actions, disencumbered of the strictures of pecuniary repute. Given that the instinct of workmanship responded strongest to potential communal benefits, Veblen's proposition amounted to a pragmatist endorsement of democracy as a cultural project, encompassing questions of political economy but extending well beyond them. Indeed, Veblen commended cultivation of the social, workmanlike instinct for beauty on democratically pragmatist grounds: that is, on grounds that it would best serve the interests, ideal and material, of the greatest diversity of individual human beings, now and in the long run. Whereas the "self-regarding" ethos of modern barbarism ironically resigns a populace to subjection by a "ruling class," he wrote, a "workmanlike" ethos focuses collective attention and efforts on the "fulness of life of the group" - including "the welfare of the young and the prospective fortunes of the group." ${ }^{44}$ 
27 In sum, Veblen believed intelligence allowed humans to adapt their behavior to context, and that the habits of workmanship were best suited to resolving the contradictions afflicting modern, industrial, interdependent society: a society that, despite its gross productivity, visited "loss of life and livelihood" on millions, wove a "tissue of dissension" within and among nations, and threatened "mutual and collective defeat and grief" for the race. ${ }^{45}$ This belief that even a highly dysfunctional social order can be reimagined and reformed through a marriage of ideals and practice puts Veblen in the company of James and Dewey, and marks all three as forerunners of social aesthetics. It also gains support and relevance from two otherwise disparate fields of contemporary inquiry: cultural evolutionary theory and public work philosophy.

\section{The Public Work of Cultural Evolution}

Despite his critique of modern industrialized societies, Veblen saw the potential for their renewal if the right anthropological and political resources could be tapped. Veblen believed in "a generically human type of spiritual endowment." Populations across time and space exhibited striking differences, but each "racial type" was nevertheless best adapted to the circumstances of its emergence, circumstances fundamentally similar for all. Thus, across the human race, "the exigencies to which its spiritual (instinctive) nature was selectively required to conform" were those of peaceable hunting, gathering, recreation, and cooperative governance - "those of the savage culture." ${ }^{46}$

As discussed, this generic, savage mind lurking beneath the habituated modern consciousness had a native aesthetic sense, to which some phenomena appealed regardless of their implications for efficient (or wasteful) activity. Nonetheless, Veblen thought that the highest beauty satisfied the economic instincts as well; efficiency enhanced intrinsic beauty. Like beauty, he understood economic utility in terms of the generic human type: a "social animal" whose primitive gregariousness was compounded and enhanced by conditions of the savage phase. By 1898 Veblen had concluded that during those early, industrially primitive stages of human development, only a "sense of solidarity" more powerful than self-interest could sustain the groups that in turn sustained their members. In 1914 he based an entire book - The Instinct of Workmanship - on the assumption that the "prime requisite for survival" under savage conditions was "a penchant for turning all resources of knowledge and material to account to sustain the life of the group." ${ }^{47}$

A growing body of contemporary research in human evolution supports Veblen's account of these native social-aesthetic resources. Christian Cordes, for instance, identified several echoes of Veblen's work in his 2005 survey of relevant cognitive science literature. These include the claims that "cognitive dispositions" (what Veblen called instincts) help explain the "profound contemplation and facile dissemination" of some ideas rather than others; that the interaction of instinct and "human creativity" can produce a social "tendency" (what Veblen called a habit or institution) that in turn influences expression of cognitive dispositions; and that through such processes, "an institutionalized habit to perform useful or productive work may [be expected to] emerge as a feature of social evolution" across human cultures. ${ }^{48}$ In sum, the cognitive science literature suggests just what Veblen argued. The species has evolved an 
instinctive appreciation for efficient and useful work. As part of a complex system of other cognitive dispositions and cultural traditions, this instinct can express itself in widely varying and seemingly contradictory ways. Nevertheless, it remains a powerful driver of individual and collective behavior.

Advances in cultural evolutionary theory confirm this argument while bolstering two additional claims central to Veblen's constructive project. First, cultural evolutionists are nearly unanimous in endorsing Veblen's claim that human individuals can and often do perceive efficiency, utility, and even their own self-interest in social terms, or as Veblen would say, in terms of "the life of the group." Modern homo sapiens emerged from a "multi-level selection" process in which selection between proto-human groups counterbalanced selection within them to favor groups of internally cooperative members over groups of internally competitive members. The result was what evolutionists call a "major evolutionary transition": an instance of group members cooperating so well that they collectively evolve into a higher-order organism or superorganism. ${ }^{49}$ In this case, the organism evolved an ability to subject its instincts to the discipline of taught, learned, and collectively enforced behavior far outstripping the capacities of its closest genetic cousins, bonobos and chimps. Along the way, it developed a remarkable capacity for environmental adaptation, achieved near ubiquitous dispersion, and effectively exited the food chain. Crucially, moreover, humanity's major evolutionary transition was of the "egalitarian" rather than "fraternal" variety, favoring behaviors with prosocial benefits extending beyond close relatives to the general membership of a much larger group. In other words, our ancestors created cultural systems that both reflected and favored the genetic evolution of vigilantly egalitarian modes of thinking. ${ }^{50}$

31 Second, cultural evolutionary theory supports Veblen's idea that our prosocial instincts, though perverted by powerful antisocial institutions, can and must be harnessed to more objectively prosocial ends. For many prominent investigators, cultural evolutionary theory does more than just explain the transmission, selection, and adaptation of human behaviors. It is also a vindication of cooperation's role in human flourishing and a tool for determining how best to support cooperation across multiple scales of social organization. ${ }^{51}$ Like Veblen, cultural evolutionists accept that, with the development of agriculture, the scale of human society began to outstrip humans' genetically evolved ability to hold each other in check, permitting despotisms to arise. On the other hand - and also like Veblen - many insist that the egalitarian impulse was conserved, due in large part to the collective advantage enjoyed by relatively more egalitarian societies over relatively less ones. After all, nearly every society for which records exist has devised mores, rituals, disciplinary systems, and government institutions that constrain elites to some degree. Meanwhile, history's most stable, vigorous societies seem to be those whose members believe, in the main, that they enjoy the highest levels of moral equality and social equity practicable. ${ }^{52}$ The upshot, at least for some cultural evolutionists, is that the evolution of learned, taught, and enforced behaviors can be managed by the very human groups undergoing it, and that it can and should be managed to maintain this unique - and inherently cooperative - advantage.

32 This argument finds highly elaborated form in the works of cultural evolutionist David sloan Wilson. For Wilson, the small group remains a critical unit of human social organization, essential to effective (i.e., life- and health-sustaining) action at both the 
individual and large-group scales. Indeed, our evolved and highly successful capacity to cooperate in small groups challenges two major narratives of progress that each reinforce a debilitating binary between individual and large-scale action: laissez faire and centralized planning. Laissez faire, Wilson argues, goes wrong because the unregulated pursuit of lower-level (individual) interests impedes the maintenance and restricts the scope of higher-level (population) wellbeing. Centralized planning goes wrong because the relations among individual and collective interests are too complex for any group of experts to negotiate alone, and because ongoing management of a dynamic environment requires a large and steady stream of individual innovations to consider and test. What can work, Wilson argues, is a "managed process of cultural evolution" in which practices perceived to benefit small but internally diverse groups are explicitly chosen as targets of selection, experimentally employed at multiple scales and in a range of conditions, and consciously replicated in ways that promote the most successful while remaining sensitive to varying social context..$^{53}$

These arguments underwrite and enhance Veblen's social-aesthetic project. Although Veblen thought the instinct of workmanship was frustrated by predatory institutions inherited from the past, he did not deem it entirely absent from or incompatible with modern society. If freed from the invidious canon of waste, he argued, the instinct of workmanship would promote behaviors that were better adapted to modern industrial society, precisely because of their prosocial character. "The collective interests of any modern community centre in industrial efficiency," he wrote, and "efficiency" required the "peacefulness" fostered by empathy and "absence of self-seeking." ${ }^{4}$ Should the waste of predatory conventions be publicly exposed, the instinct of workmanship would interact with other propensities, such as imitation and emulation, to narrow the gap between technological and cultural evolution. Innovations facilitating "human life on the whole," rather than the "interest of one as against another," would be emulated - including pursuits satisfying another of humankind's primal instincts, the "parental bent," which extended concern for one's children to include concern for human life in the abstract..$^{55}$ Veblen's belief that a taste for serving the community and its heirs might "catch on," so to speak, and prove itself prerequisite to continued technological development, indicates his conviction that our deepest aesthetic, economic, and ethical drives are prosocial in origin and purpose - just as cultural evolutionists like Wilson maintain. ${ }^{56}$

But how did Veblen envision this managed evolution toward a more cooperative, egalitarian social system taking place? The workplace was a key site for Veblen, and in this he anticipated political theorist Harry C. Boyte and other exponents of the "public work" paradigm. Boyte defines public work as a normative, democratizing ideal in which all members of society have opportunity and capacity to shape the life they share together, imagining and producing common goods by comparing and negotiating their interests wherever they happen to interact. Democratic politics is productive, across every aspect of society, not simply distributive, emerging from the state or focused on state action; democratic citizens are producers, not simply consumers of politics. ${ }^{57}$ Public work philosophy draws on the empirically grounded theory of Elinor Ostrom - Nobel laureate in economics - who documented the importance of citizen autonomy and collective responsibility for the creation, governance, and sustainability of public resources such as fisheries, forests, irrigation systems, and other commons. Such citizen-organized, citizen-effected "work," as civic theorist Peter Levine explicitly labels it, not only "builds social capital" and "strengthens communities," but "gives 
people the skills they need for collective citizenship" generally - whether in daily interactions with neighbors, classmates, and colleagues or in town meetings, caucuses, or voting booths. ${ }^{58}$

Here the public work paradigm contrasts sharply with millennia of political theory, including classical Greek denigration of labor, Hannah Arendt's influential distinction between public and private realms, and contemporary civil society frameworks that reject remunerative work as a space for civic learning and action. ${ }^{59}$ Like James and Dewey before them, public work philosophers imagine institutions of every sort as complex human communities, created by human action, which can be reconstructed in more democratic ways by intentional effort. ${ }^{60}$ Democracy itself is a form of work - a collective, often arduous, but dignified and rewarding labor of "We the People" - and workplaces are potential seedbeds of democracy - hybrid private and public spaces in which a host of individual, enterprise, and community interests must be managed over time. ${ }^{61}$

Veblen, too, saw the workplace as critical to effecting an organic democratization of culture that was radical in trajectory while avoiding abrupt, overly schematic, and potentially violent change. Ironically, his hope was sparked by the very "machine process" that many contemporaries blamed for dehumanizing factory workers and debasing cultural standards of value. ${ }^{62}$ In Veblen's view, regular, close observation and interaction with the clear cause-and-effect logic of modern production discouraged workers from imputing "animistic or anthropomorphic subtleties" to material facts and their relations, prompting them to question whether personal consumption, for instance, did in fact create social value - and if so, how. This reflective and critical process, occurring in the minds of millions of workers, was eroding the framework of conventions that legitimated the predations of "business enterprise," instead encouraging judgments based on "tangible performance." In these ways, Veblen argued, the "discipline of the machine" was undermining the institutions of pecuniary competition it ostensibly served..$^{63}$

Those who share Boyte's vision of autonomous, creative, cooperative individuals developing and refining practices to advance both private and public goals might be put off by Veblen's faith in the modern industrial "machine process" as a catalyst of democratic transformation. Indeed, prominent critics have accused Veblen of endorsing an aristocracy of engineers in both the workplace and society generally. ${ }^{64}$ But Veblen's actual view of the machine process and its democratic value should allay any fears on this score. His "discipline of the machine" prefigures what Mary Dietz, another critic of the work/politics binary, has called "methodical thinking." In a trenchant comparison of "work" in the thinking of Arendt and the French Catholic syndicalist Simone Weil, Dietz commends Weil's metaphor of a sailor on the sea for suggesting the creative yet responsive habits work can foster. In sailing, the "tools of work" dominate neither sea nor sailor. Rather, they "are instruments through which the methodical thinker initiates and attempts to maintain a tentative equilibrium within circumstances that challenge and constantly change." 65

Veblen was clearly aiming at something like this understanding of work's liberating potential. The machine process did not negate human creativity, but merely vitiated the barbarian tendency to view the laws of physics as the actions of a humanoid entity with humanoid goals. In that barbarian mindset, wrote Veblen, a worker's "creative imagination" was stunted by the assumption that mechanical processes must be carried 
out according to fixed ideas of "sufficient reason" rather than "efficient cause." By contrast, machine discipline encouraged constant reevaluation of "sufficient reason" in light of changing experience and objectives, ensuring that reasons sufficient to guide activity in the past were equally sufficient in the present, and were modified if not. In effect, machine discipline encouraged the pragmatic turn of mind - and not just among an engineering elite. ${ }^{66}$ In Veblen's estimation, the critical and experimental habits of machine discipline developed at least as quickly and robustly "in the workmen under whose tendance these processes and appliances are to work out the designed results" as in the engineers overseeing them. Furthermore, the cognitive discipline of the machine was already extending beyond workers - to the kin, neighbors, merchants, clergy, officeholders, and others for whom they modeled it and from whom they came to expect it - "so as in great part to determine the habits of all members of the modern community." ${ }^{67}$

But determine to what end? How can societies manage such cultural processes so that they not only erode barbaric conventions but directly foster democratic habits, processes, and innovations? Public work philosophy provides some concrete suggestions. Public work thinkers insist that the practical wisdom of everyday citizens navigating their family circles, workplaces, and communities should directly inform the operations and significantly shape the purposes of institutions with public impact, whether those be government branches and agencies, educational and philanthropic institutions, professional associations, or businesses. In effect, public work philosophers envision an organic version of managed cultural evolution, exploiting the bridge-building, problem-solving capacity of small groups by communicating and testing their practices and conclusions across scales. ${ }^{68}$ Bringing theory to practice, public work philosophers and sympathetic researchers have documented numerous examples of such institutional "permeability" to public input. In nearly all cases, the criterion of such public permeability and learning is the intentional adoption among key personnel of an ethos Albert W. Dzur terms "democratic professionalism": an ethos in which professional, accredited experts learn from, rely upon, and feel comfortable deferring to the informal expertise of lay citizens with direct experience of the phenomena to be managed. ${ }^{69}$ This empirical and anthropological bent has also led public work philosophers and allied thinkers to highlight historical examples of citizens creating, managing, and sustaining common goods in egalitarian fashion, and resisting the elite capture and hierarchical reorganization of well-regulated commons even in the mythically individualistic United States. In colonial towns, frontier settlements, freedmen's schools, rural cooperatives, settlement houses, early agricultural extension partnerships, the locally organized relief and work projects that informed the New Deal, the citizenship schools of the early Civil Rights movement; in all these examples, and more, scholars find evidence that many of American democracy's formative developments and signal triumphs only make sense if we reject sharp distinctions between private and public, material and spiritual, selfish and civic. ${ }^{70}$ Veblen, too, believed that realizing the democratic potential of modern Western culture required tapping its democratic resources, past and present. The respect for individual autonomy and social contribution that characterized the "handicraft era," for instance, not only channeled savage norms, but also shaped the ideological justifications of modern capitalism and to that extent constrained the forms of its development. ${ }^{71}$ Looking further backward, Veblen found hope in the "impulse to mutual service" characterizing early Christianity, which indicated that savage 
humanity's "spiritual heritage" of voluntary reciprocity had survived the institutions of ownership and organized religion and thus might revivify modern economic life. After all, despite Western society's blasphemous (from a primitive Christian perspective) tendency to define individuals in terms of "pecuniary efficiency," the "Natural Rights" so often invoked to justify a competitive economic system had, ironically, borne "Rights of Man" that undermined the coercive property laws sustaining it. All this supported the hope, at least, that "the ancient racial bias embodied in the Christian principle of brotherhood" might "continue to gain ground at the expense of the pecuniary morals of competitive business."72

41 Veblen, of course, was too much a Darwinist and pragmatist to believe things destined to unfold that way. That uncertainty explains not only the character but the very existence of his social-aesthetic project. Veblen believed that the future of Western civilization depended on successful adaptation to the "altered scheme of life" its own growth had imposed, through intentional creation of conditions allowing "the ancient bent" toward social productivity to surmount the wasteful "canons of convention" that constrained it..$^{73}$ That, in turn, required a cultural commitment to social aesthetics: a commitment to encouraging individual creativity and amplifying innovations that enriched the lives of others, whether economically, intellectually, morally, or spiritually. As Veblen wrote, the "functional content" of the instinct of workmanship was "serviceability for the ends of life, whatever these ends may be." ${ }^{74}$ Accordingly, its ideal object was what public work philosophy would call a "commonwealth": a world of shared spaces, technologies, ideas, and even ideals, created and sustained by diverse, cooperating human beings. ${ }^{75}$

\section{Democratic Culture: A Public Work in Progress}

So what does Veblen's pragmatist, cultural-evolutionary, public-work aesthetics offer the social-aesthetics field?

One contribution is Veblen's refusal to imagine, analyze, or interpret aesthetic experience as distinct from other forms of human experience - a refusal critical to any constructive social aesthetics. Asserting, against Kant, that perceptions of beauty suggest social purposes, Veblen anticipated efforts by later theorists to examine "the many ways in which individual aesthetic judgments are influenced by social processes and pleasures." ${ }^{\prime 6}$ But Veblen went further, suggesting that the social did not just mediate aesthetic experience but largely generated it. ${ }^{77}$ For Veblen, society was the primary vehicle by which mental freedom and external reality were reconciled, through cooperative, creative action - a collaborative work of art. In this view the increasing interdependence of modern society does not just demand a social aesthetics to expose the political functions of aesthetic judgments. ${ }^{78}$ It also expands the scope of phenomena with which the purposeful individual must negotiate, multiplying her opportunities to experience practical freedom and inviting a constructive, pragmatic social aesthetics to help her maximize them.

This points to Veblen's second contribution: a definition of social aesthetics that might satisfy multiple field architects while inviting cooperation from other fields. From a Veblenian perspective, aesthetic inquiry includes but cannot be limited to art's social purposes. It must explore and promote the ways that our aesthetic sensibilities can explain and serve the whole range of human purposes - or rather, as Arnold Berleant 
suggests, all human purposes that do not restrict the "mutually fulfilling activities" of other humans. ${ }^{79}$ Such an orientation complements Georgina Born's challenge to aesthetic theorists to delve more deeply in the work of disciplines such as sociology and anthropology, and Jennifer A. McMahon's efforts to link social aesthetics directly to moral theory and theories of embodied cognition. ${ }^{80}$ By emphasizing the inextricability of humanity's aesthetic, evolutionary, and cultural development, however, Veblen expands the range of disciplines relevant to aesthetics while also making aesthetics fundamental to sciences both "hard" and "soft." "For the large generality of human knowledge," Veblen wrote, "...the raw material of observed facts is selectively worked over, connected up and accumulated on lines of a putative teleological order, cast in something like a dramatic form" - one "that instinctively commends itself to the workmanlike sense of fitness." "Social aesthetics thus becomes the effort to understand the conditions of "moderately advanced savagery" that encouraged humans to value knowledge for its public utility and its subjective beauty, and to recreate them in adapted form..$^{82}$ Simultaneously, however, a Veblenian attitude can insulate the aesthetic realm from the technocratic colonization that a "science" of social aesthetics might invite. Affirming that some objects, experiences, and ideas strike people as beautiful regardless of material or social use, and suggesting how such judgments can arise through spontaneous variation and replicate genetically or culturally, Veblen reminds the aspiring social engineer that pure pleasure is a social good, and experts should never assume they know what will provide it.

Veblen's third contribution is to point toward the practical political implications of his social aesthetics. Here the congruence of Veblen's thought with that of Dewey is instructive. The congruence is unsurprising: Both thinkers drew their fundamental psychological assumptions from James. Having begun his philosophical career as a Hegelian, Dewey credited James's Principles with sealing his embrace of experience as the source of truth, and his conception of knowledge as a function of active, iterative adjustment and readjustment to experience. ${ }^{83}$ Meanwhile, Dewey and Veblen shared similar ideas about the role of aesthetic judgment in human thought. In Art as Experience (1934), Dewey wrote that coherent thinking "has its own esthetic quality," an "internal integration and fulfillment reached through ordered and organized movement." Not only did such "consummation" of thought motivate inquiry, but no intellectual activity was truly an "experience" unless it was "rounded out" this way. Accordingly, the most gratifying courses of action lay between "the poles of aimlessness and mechanical efficiency," seeking the harmonization of our own purposes with the facts of the external world. ${ }^{84}$

These congruencies with Veblen's writings are joined in Dewey's corpus to an explicit defense of democracy as a cooperative community of inquiry. Dewey drew explicitly on James's theory of the social self to argue that human beings' full self-realization depends on the practical and acknowledged public value of their activities, and thus on the communicability and congeniality of their ideals and justifications to those of other individuals. Mutual satisfaction among such a diversity of willful yet dependent individuals hinges on "trained powers of initiative and reflection" that only a "freely cooperative" democracy can foster. ${ }^{85}$ The ideal model for such a democracy, in Dewey's view, was science, understood not as a discrete body of knowledge but as a set of agreed yet evolving practices for collectively solving problems. For Dewey, such a "scientific" democracy was also a "moral" democracy, for by treating ideals and convictions as hypotheses to be tested against a wide range of human experience, it offered a practical 
(if never final) means of reconciling freedom with social responsibility. The "basic" meaning of democracy, Dewey granted, remained "faith in individuality" and the "unique modes of creative activity that create new ends." ${ }^{86}$ Yet that faith could only be realized in communities structured by "free and open communication, unself-seeking and reciprocal relationships, and the sort of interaction that contributes to mutual advantage." ${ }^{\prime 7}$ The challenge of modern politics, in Dewey's view, was to create democratic communities that encouraged such democratic communication - and like latter-day cultural evolutionists, he believed this needed to happen at multiple scales. Throughout his career, therefore, Dewey supported efforts he thought could invigorate "local community life" as well as foster a "great community" at national scale, including settlement houses; community schools; extension and other highereducation outreach programs; cooperative management and ownership of factories; and nationalization of industries with power to restrict, disincentivize, or ignore public input into public matters. ${ }^{88}$

Dewey's ideas for social and political reconstruction are important to a Veblenian social aesthetics because they help to flesh out implications toward which Veblen only gestured. The Jamesian genealogy and aesthetic account of knowledge that both thinkers share make it plausible, at least, that Deweyan solutions to some of the cultural evolutionary problems Veblen identified would have been endorsed by the latter. Indeed, Veblen called, in print, for the type of self-governing workplace and public control of critical industries that Dewey advocated. ${ }^{89}$ Embracing a Deweyan defense of free communication and reciprocal relationships, Veblen also privately chastised the government for failing to cooperate with labor radicals to relieve the agricultural labor shortage during the First World War. ${ }^{90}$ True, Veblen sometimes struck a more radical note than Dewey; in 1917, for example, Veblen declared "abrogation of the rights of ownership" the precondition for both domestic and international peace. ${ }^{91}$ But as he explained in a 1918 memorandum for the US peaceplanning group, the Inquiry, his main goal was to dislodge the vested interests who fattened on war and its causes, including "national ambitions" manufactured by plutocrats seeking escape valves for domestic tensions. ${ }^{92}$ Nowhere did Veblen suggest a comprehensive, state-sponsored abolition of private property. Like Dewey, he seems to have accepted that collectively managed evolution and sweeping, drawing-board reform by the state are incompatible: dictate - or revolution - was a shaky foundation upon which to build a cooperatively adaptive culture.

On the other hand, Veblen's social aesthetics can advance Dewey's project of a "great community" in a way that Dewey's own writings have not: through Veblen's sustained, even relentless emphasis on work. This emphasis confers two advantages on a Deweyan democratic project otherwise heavily (and often interpreted as purely) focused on deliberation. First, it trains attention on power. Veblen's emphasis on the asymmetry of socially valuable and socially valued work highlights the power inequities that structure communicative exchanges more distinctly than Dewey's emphasis on consensus as a regulative ideal..$^{93}$ At the same time, Veblen's account of the inherent attractiveness to human beings of socially promising and socially valued work points to the multiplicative and integrative aspect of power; though divisive and corruptive when concentrated, power is unifying and invigorating when shared. ${ }^{94}$ Second, Veblen's focus on work reminds us that a major predicate of productive communication is empathy, and that one way human beings build empathy is by observing - or better 
yet, joining in - one another's efforts to turn materials, experience, or ideas to creative, productive use..$^{95}$

The central political import of Veblen's social aesthetics, therefore, may be that a pragmatist version of public work, promoting norms and practices that simultaneously encourage, value, channel, and vet the aesthetic impulses of individuals, is essential to reaching the state of managed cultural evolution that Wilson and others envision. It is not enough to expose the contingency of institutions, or identify those that best explain and promise to maintain the biological success of the human race. That biological success seems inextricably linked to our tolerance - even, at times, our preference - for innovations and conditions that have no immediately discernible purpose other than to promote what Veblen called the "free movement of the human spirit." ${ }^{96}$ Like the pragmatists, many cultural evolutionists, and public work philosophers, Veblen realized that human choices rather than natural laws were the primary impediments to such "free movement" of spirit. At the same time, as Veblen impressed upon his stepdaughter, there flowed through all his criticism "an undercurrent of faith in human capabilities for good... an awareness of all that W. James and others were making common knowledge." ${ }^{17}$

Social aesthetics should focus on reminding humans that they are not mere organisms responding mechanically to stimuli but are instead subjective, moral, social beings. We seek fitness between ourselves and our interests and our experience. That experience includes other people, their actions, and the interests we infer from them. At some instinctual level, we desire to refine our interests and alter our practices to better harmonize with the interest and actions of others. That social-aesthetic process of education is not a relinquishment of freedom. It is an embrace of freedom; an enhancement of our creative potential to order our world by learning from and working with its most dynamic and consequential parts: other people. It is democracy; and despite his rhetorical nostalgia for "savagery," Veblen's suggestive renderings of a democratic future endure and inspire.

\section{BIBLIOGRAPHY}

ADORNO Theodor W., (1941), "Veblen's Attack on Culture," Studies in Philosophy and Social Science, 9, 389-413.

ALLPORT Gordon Willard, (1954), The Nature of Prejudice, Boston, Addison-Wesley.

ARENDT Hannah, (1958), The Human Condition, Chicago, University of Chicago Press.

BARBER Benjamin R., (1998), A Place for Us: How to Make Society Civil and Democracy Strong, New York, Hill \& Wang.

BELL Daniel, (1963), "Veblen and the New Class," American Scholar, 32, 616-38.

BERLEANT Arnold, (1992), The Aesthetics of Environment, Philadelphia, Temple University Press. 
BERLEANT Arnold, (1997), Living in the Landscape: Toward an Aesthetics of Environment, Lawrence, University Press of Kansas.

воЕнм Christopher, (1993), "Egalitarian Behavior and Reverse Dominance Hierarchy," Current Anthropology, 34, 227-40.

BOURDIEU Pierre, (1979/2001), "Distinction: A Social Critique of the Judgment of Taste," in V. B. Leitch et al. (eds), The Norton Anthology of Theory and Criticism, New York, W.W. Norton and Company.

BORN Georgina, (2010), “Listening, Mediation, and Event: Anthropological and Sociological Perspectives," Journal of the Royal Musical Association, 135, S1, 79-89.

BORN Georgina, LEWIS Eric \& Will STRAW, (2017), "Introduction: What is Social Aesthetics?," in Id. (eds), Improvisation and Social Aesthetics, Durham, NC, Duke University Press.

BoYTE Harry C., (1989), CommonWealth: A Return to Citizen Politics, New York, Free Press.

BOYTE Harry C., (1999), "Off the Playground of Civil Society," The Good Society, 9, 1-7.

BOYTE Harry C., (2004), Everyday Politics: Reconnecting Citizens and Public Life, Philadelphia, Penn Press.

BOYTE Harry C., (2011), “Constructive Politics as Public Work,” Political Theory, 39, 630-60

BOYTE Harry C., (2018), Awakening Democracy through Public Work: Pedagogies of Empowerment, Nashville, TN, Vanderbilt University Press.

BOYTE Harry C., (2020), “Democratic Populism as Constructive Nonviolence," in A. Ron \& M. Nadesan (eds), Mapping Populism: Approaches and Methods, Abingdon, UK, Routledge.

BOYTE Harry C. \& Sara M. EVANS, (1986), Free Spaces: The Sources of Democratic Change in America, Chicago, University of Chicago Press.

BOYTE Harry C. \& Nancy N. KARI, (1997), “The Commonwealth of Freedom," Policy Review, November/December, 41-5.

BUDD John W., (2011), The Thought of Work, Ithaca, NY, Cornell University Press.

CAMIC Charles, (2020), Veblen: The Making of an Economist Who Unmade Economics, Cambridge, Mass., Harvard University Press.

CORDES Christian, (2005), “Veblen's 'Instinct of Workmanship,' Its Cognitive Foundations, and Some Implications for Economic Theory,” Journal of Economic Issues, 39, 1-20.

CREANZA Nicole, KOLODNY Oren \& Marcus W. FELDMAN, (2017), "Cultural Evolutionary Theory: How Culture Evolves and Why It Matters," PNAS, 114, 7782-9.

DEWEY John, (1909), “A Short Catechism Concerning Truth,” MW.6.3-5.

DEWEY John, (1916), “The Need of an Industrial Education in an Industrial Democracy,” MW.

10.137-43.

DEWEY John, (1922), “Individuality, Equality, and Superiority,” MW.13.295-300.

DEWEY John, (1927), The Public and Its Problems, LW.2.369-72.

DEWEY John, (1934), Art as Experience, LW.10.

DEWEY John, (1973), Lectures in China: 1919-1920, trans. and ed. by R. W. Clopton \& T.-C. Ou, Honolulu, University of Hawaii Press. 
DEWEY John \& James Hayden TUFTS, (1908), Ethics, MW.5.

DIETZ Mary, (1994), “'The Slow Boring of Hard Boards': Methodical Thinking and the Work of Politics," American Political Science Review, 88, 873-86.

DIGGINS John P., (1978), The Bard of Savagery: Thorstein Veblen and Modern Social Theory, New York, Seabury Press.

DIGGINS John P., (1993), "Thorstein Veblen and the Literature of the Theory Class," International Journal of Politics, Culture, and Society, 6, 481-90.

DZUR Albert W., (2017), Rebuilding Public Institutions Together: Professionals and Citizens in a Participatory Democracy, Ithaca, NY, Cornell University Press.

DZUR Albert W., (2019), Democracy Inside: Participatory Innovation in Unlikely Places, New York, Oxford University Press.

DORFMAN Joseph, (1973), "New Light on Veblen," in T. Veblen, Essays, Reviews, and Reports: Previously Uncollected Writings, ed. J. Dorfman, Clifton, NJ, A.M. Kelley.

DYER Alan W., (1986), "Veblen on Scientific Creativity: The Influence of Charles S. Peirce," Journal of Economic Issues, 20, 21-41.

EAGLETON Terry, (1990), The Ideology of the Aesthetic, Gateshead, UK, Wiley-Johnson.

FIALA Andrew G., (2000), "Aesthetic Education and the Aesthetic State," in W. Maker (ed.), Hegel and Aesthetics, Albany, SUNY Press.

FITE Warner B., (1933), “Warner B. Fite to Joseph Dorfman, March 1, 1933,” Joseph Dorfman Papers, Columbia University.

HAMmeRmeISTER Kai, (2002), The German Aesthetic Tradition, Cambridge, UK, Cambridge University Press.

HENRICH Joseph, (2015), The Secret of Our Success: How Culture is Driving Human Evolution, Domesticating Our Species, and Making Us Smarter, Princeton, NJ, Princeton University Press. HEWSTONE Miles, (2015), “Consequences of Diversity for Social Cohesion and Prejudice: The Missing Dimension of Intergroup Contact," Journal of Social Issues, 71, 417-38.

HoDGSON Geoffrey M., (2004), The Evolution of Institutional Economics: Agency, Structure and Darwinism in American Institutionalism, London, Routledge.

JAMES William, (1890/1896), The Principles of Psychology, 2 vols., New York, Henry Holt, Veblen Special Collection nos. 129 and 130, Carleton College, Northfield, Min., USA.

JAMES William, (1899), "What Makes a Life Significant?," in Id., Talks to Teachers on Psychology, and to Students on Some of Life's Ideals, New York, Henry Holt.

KLOPPENBERG James T., (1986), Uncertain Victory: Social Democracy and Progressivism in European and American Thought, 1870-1920, New York, Oxford University Press.

LEVINE Peter, (2006), "Collective Action, Civic Engagement, and the Knowledge Commons," in C. Hess \& E. Ostrom (eds), Understanding Knowledge as a Commons: From Theory to Practice, Boston, MIT Press.

LEVINE Peter, (2013), We Are the Ones We Have Been Waiting For: The Promise of Civic Renewal in America, New York, Oxford University Press.

MARGULIS Lynn, (1971), "Symbiosis and Evolution,” Scientific American, 224, 48-57. 
MATHEWs David, (2006), Reclaiming Public Education by Reclaiming Our Democracy, Dayton, OH, Kettering Foundation.

MCMAHON Jennifer A., (ed.), (2018), Social Aesthetics and Moral Judgment: Pleasure, Reflection, and Accountability, Abingdon, UK, Routledge.

MESLE C. Robert, (2016), "Relational Power, Personhood, and Organizations," in J. HowardGrenville, C. Rerup, A. Langly \& H. Tsoukas (eds), Organizational Routines: How They Are Created, Maintained, and Changed, Oxford, Oxford University Press.

OKASHA Samir, (2006), Evolution and the Levels of Selection, Oxford, Oxford University Press.

OSTROM Elinor, (1990), Governing the Commons: The Evolution of Institutions for Collective Action, Cambridge, UK, Cambridge University Press.

PERRY Ralph Barton, (1935), The Thought and Character of William James, 2 vols., Boston, Little, Brown.

PETERS Scott J., (2006), “Every Farmer Should Be Awakened: Liberty Hyde Bailey's Vision of Agricultural Extension Work," Agricultural History, 80, 190-219.

PETTIGREW Thomas Fraser \& Linda R. TROPP, (2006), “A Meta-Analytic Test of Intergroup Contact Theory," Journal of Personality and Social Psychology, 90, 751-83.

PLOTKIN Sidney \& Rick TILMAN, (2011), The Political Ideas of Thorstein Veblen, New Haven, CT, Yale University Press.

RICHARDSON Robert D. Jr., (2006), William James: In the Maelstrom of American Modernism, Boston, Houghton Mifflin.

RICHERSON Peter, BALDINI Ryan, BELL Adrian V., DEMPS Kathryn, FROST Karl, HILLIS Vicken, MATHEW Sarah, NEWTON Emily K., NAAR Nicole, NEWSON Lesley, Ross Cody, SMALDINO Paul E., WARING Timothy M. \& Matthew ZEFFERMAN, (2016), "Cultural Group Selection Plays an Essential Role in Explaining Human Cooperation: A Sketch of the Evidence," Behavioral Brain Science, 39, 1-19.

RICHERSON Peter J. \& Robert BOYD, (2005), Not by Genes Alone: How Culture Transformed Human Evolution, Chicago, University of Chicago Press.

ROGERS Melvin L., (2012), The Undiscovered Dewey: Religion, Morality, and the Ethos of Democracy, New York, Columbia University Press.

SHKLAR Judith N., (1991), American Citizenship: The Quest for Inclusion, Cambridge, Mass., Harvard University Press.

SMITH John Maynard \& Eörs SZATHMÁRY, (1999) The Origins of Life: From the Birth of Life to the Origin of Language, Oxford, Oxford University Press.

STARMANS Christina, SHESKIn Mark \& Paul Bloom, (2017), "Why People Prefer Unequal Societies," Nature Human Behavior, 1, 1-7.

TAYLOR Gerald, (2012), "Prometheus Unbound: Populism, the Property Question, and Social Invention," The Good Society, 21, 219-33.

THRONTVEIT Trygve, (2008), “The Will to Behold: Thorstein Veblen's Pragmatic Aesthetics," Modern Intellectual History, 5, 519-546.

THRONTVEIT Trygve, (2011), “William James's Ethical Republic," Journal of the History of Ideas, 72, 255-77. 
THRONTVEIT Trygve, (2014), William James and the Quest for an Ethical Republic, New York, Palgrave. THRONTVEIT Trygve, (2017), Power without Victory: Woodrow Wilson and the American Internationalist Experiment, Chicago, University of Chicago Press.

TILMAN Rick, (1996), The Intellectual Legacy of Thorstein Veblen: Unresolved Issues, Westport, Connecticut, Praeger.

TILMAN Rick, (2004), Thorstein Veblen, John Dewey, C. Wright Mills, and the Generic Ends of Life, Lanham, Md., Rowman and Littlefield.

TILMAN Rick, (2007), Thorstein Veblen and the Enrichment of Evolutionary Naturalism, Columbia, University of Missouri Press.

TURCHIN Peter, (2016), Ultrasociety: How 10,000 Years of War Made Humans the Greatest Cooperators on Earth, Chaplin, Connecticut, Beresta Books.

VEBLEN Andrew, (1926), “Andrew A. Veblen to Joseph Dorfman,” Andrew Veblen Papers, 1926, October 1, Minnesota Historical Society, St. Paul.

VEBLEN Andrew, (1930), “Andrew A. Veblen to Joseph Dorfman,” Andrew Veblen Papers, July 12, 1930, Minnesota Historical Society, St. Paul.

VEBLEN Thorstein, (1891), "Some Neglected Points in the Theory of Socialism," Annals of the American Academy of Political and Social Science, 2, 57-74.

VEBLEN Thorstein, (1898a), “The Beginnings of Ownership,” American Journal of Sociology, 4, 352-65. VEBLEN Thorstein, (1898b), “The Instinct of Workmanship and the Irksomeness of Labor," American Journal of Sociology, 4, 187-201.

VEBLEN Thorstein, (1898c), “Why is Economics Not an Evolutionary Science?," Quarterly Journal of Economics, 12, 373-97.

VEBLEN Thorstein, (1899/1994), The Theory of the Leisure Class, New York, Dover Publications. VEBLEN Thorstein, (1904), The Theory of Business Enterprise, New York, C. Scribner's Sons. VEBLEN Thorstein, (1906), "The Place of Science in Modern Civilization," American Journal of Sociology, 11, 585-609.

VEBLEN Thorstein, (1908/1919), "The Evolution of the Scientific Point of View," in Id., The Place of Science in Modern Civilization and Other Essays, New York, B.W. Huebsch.

VEBLEN Thorstein, (1914), The Instinct of Workmanship and the State of the Industrial Arts, New York, Macmillan.

VEBLEN Thorstein, (1915), Imperial Germany and the Industrial Revolution, New York, Macmillan.

VEBLEN Thorstein, (1917), On the Nature of Peace and the Terms of Its Perpetuation, New York, Macmillan.

VEBLEN Thorstein, (1919), The Vested Interests and the Common Man, New York, B.W. Huebsch. VEBLEN Thorstein, (1921), The Engineers and the Price System, New York, B.W. Huebsch. VEBLEN Thorstein, (1923), Absentee Ownership and Business Enterprise in Recent Times, New York, B.W. Heubsch.

VEBLEN Thorstein, (1932), “Using the I.W.W. to Harvest Grain,” ed. J. Dorfman, The Journal of Political Economy, 40, 796-807. 
VEBLEN Thorstein, (1934), Essays in Our Changing Order, ed. L. Ardzrooni, New York, Viking Press. WESTBROOK Robert B., (1991), John Dewey and American Democracy, Ithaca, NY, Cornell University Press.

WILson David Sloan, (2015), Does Altruism Exist? Culture, Genes, and the Welfare of Others, New Haven, CT, Yale University Press.

WILSON David Sloan, (2019), This View of Life: Completing the Darwinian Revolution, New York, Pantheon.

WILSON David Sloan \& John M. GowDY, (2015), "Human Ultrasociality and the Invisible Hand:

Foundational Developments in Evolutionary Science Alter a Foundational Concept in Economics," Journal of Bioeconomics, 17, 37-52.

WILSON David Sloan \& Elliott SOBER, (1989), "Reviving the Superorganism," Journal of Theoretical Biology, 136, 377-56.

WILSON David Sloan \& Edward O. WILSON, (2007), "Rethinking the Theoretical Foundation of Sociobiology," Quarterly Review of Biology, 82, 327-48.

\section{NOTES}

1. This is true even among those who find his writings valuable for political theory: see, e.g., Plotkin \& Tilman 2011. As Tilman has noted elsewhere, many of Veblen's other critics accuse him of rejecting politics entirely, on grounds that incremental reform could never dislodge vested interests' control over policymaking: Tilman (1996: 119-20). Such charges are unpersuasive; for one thing, they ignore Veblen's arguments during World War I that the liberal state, through its controlling actors, should pursue social and economic reorganization in order to maintain itself: see Veblen 1917, esp. chapter 7.

2. Boyte 2011.

3. On Veblen's persistent characterization as "outsider" or "misfit" in economic, historical, philosophical, and sociological literatures, see Camic (2020: 5-6).

4. Diggins 1978. On pragmatism as product and shaper of modernist thought and culture, see Richardson 2006.

5. Camic 2020 is the most comprehensive account of Veblen's intellectual journey to these conclusions.

6. Hodgson 2004.

7. Adorno (1941: 391, 391n4, 411-3).

8. Tilman (2004: 201); Tilman (2007: 160).

9. Throntveit 2008.

10. Thorstein Veblen, “Kant's Critique of Judgment” (1884), in Veblen (1934: 189-91, 182-3).

11. Veblen (1906: 590); Dyer (1986: 28-30). On the likelihood of Veblen reading Schiller, see Throntveit (2008: 523-4). As Dyer's title suggests ("Veblen on Scientific Creativity: The Influence of Charles S. Peirce"), it is possible that another pragmatist influenced Veblen's idea of "idle curiosity": Dyer's article analyzes the similarities between the Veblenian concept previously described as aesthetic induction, which anticipated "idle curiosity" in his thinking, and Charles Peirce's concept of "abduction," both of which Dyer likens to Schiller's "play." Yet the only evidence that Peirce influenced Veblen is Veblen's attending Peirce's lectures at Johns Hopkins; and as Veblen's brother and fellow matriculant Andrew recalled, Peirce's course required "extensive knowledge of formal mathematics, and I do not think Th.[orstein] would have enjoyed it." (Dyer 1986: 25, 30-1); A. Veblen 1926, October 1. 
12. Veblen (1906: 590-1, 604). This claim that humans, through imaginative acts, take pleasure in establishing an almost social relationship between themselves and the external world is perhaps Veblen's strongest echo of Schiller, for whom play denoted the spiritual fulfillment achieved through activities mitigating the alienation from nature that accompanies self-awareness. See Hammermeister (2002: 42-61).

13. Veblen 1891.

14. Hammermeister (2002: 23, 36-9, 44-59); Fiala 2000; Veblen (2015: esp. 225-9, 228n).

15. Veblen (1908/1919: 32-3).

16. Veblen (1898c: 390); Veblen (1898b: 189-90).

17. James (1890/1896); Throntveit (2008: 527-30).

18. Veblen (1898b: 188).

19. James (1890/1896: 1:166-8).

20. Veblen (1906: 588).

21. Veblen (1906: 588-90).

22. Veblen (1906: 592, 600); at 600 Veblen cites "James, Psychology, Vol. II, chap. 28, pp. 633-71, esp. p. 640 note" - James' chapter on "Necessary Truths and the Effects of Experience," which charts a middle course between Spencerian empiricism and idealism. In the section Veblen cited, James argued that all object-relations of thought were imagined, while so-called "scientific" relations were merely imagined relations that experience proved "congruent with the time- and space-relations which our impressions affect." The note highlighted begins: "The aspiration to be 'scientific' is such an idol of the tribe to the present generation, is so sucked in with his mother's milk by every one of us, that we find it hard to [...] treat it freely as the altogether peculiar and one-sided subjective interest which it is [...]." James (1890/1896: 2:639-40).

23. Veblen (1906: 592).

24. Veblen 1898b; Veblen (1914: 38-9).

25. Veblen (1899/1994: 92).

26. Veblen (1899/1994: 92, 94).

27. Veblen (1899/1994: 72, 94).

28. Veblen (1899/1994: 79).

29. Veblen (1899/1994: 135); Veblen (1898b: 190).

30. Veblen (1914: 38-9). Oddly, in this work Veblen cited James's Principles to support his adaptively teleological understanding of instincts, yet criticized James for presenting instincts as "determinate" and ignoring the "spiritual complex into which they all enter" $(4,8)$. Veblen overlooked, in 1914, what he read in the same chapter, "Instinct," years earlier: that every instinct "must take its chances" with all the others, and "sometimes succeed, and sometimes fail, in drafting off the currents [of stimulus] through itself" - so that "irregularities" of expression were expected. James (1890/1896: 2:391-2).

31. The three works referenced are Veblen 1898a, 1898b, 1898c. On these articles' incorporation into Leisure Class see Dorfman (1973: 251-2). Veblen was at the University of Chicago when he authored these works, where colleagues John Dewey and George H. Mead, close students of James's work, likely spurred his own interest in James: Andrew Veblen recalled that he and his brother Thorstein "talked quite a good deal together about the men in the University of Chicago," and one colleague maintained that the instinct-psychology Veblen was then refining "was in line with James and against Spencer" (A. Veblen 1930, July 12; W. B. Fite 1933, March 1). For more direct evidence of James's influence, see James (1890/1896: 2), chapters 24, "Instinct," and 28, "Necessary Truths and the Effects of Experience." A characteristic ink-blot appears on p. 423, flanking a section in "Instinct" discussing (unsurprisingly) "appropriation." Similar markings appear in the chapter on "Necessary Truths," which, as previously noted (note 22) Veblen cited in print.

32. James (1890/1896: 2:383, 390-1, 625-76); Veblen (1899/1994: 92). 
33. James (1890/1896: 2:591-2). John P. Diggins often has called attention to what he sees as Veblen's critique of philosophical pragmatism; see, e.g., Diggins (1993: 486).

34. Veblen (1906: 591n4). Indeed, Veblen later cited James' Principles as recognizing in 1890 the “idle curiosity" Veblen first discussed in 1906; Veblen (1914: 85).

35. James (1899: 273); Veblen (1906: 591, 609).

36. On classical pragmatism as a search for a philosophical and political via media see Kloppenberg 1986, esp. Part I.

37. Veblen (1899/1994: 9-10).

38. Veblen (1899/1994: 94).

39. James (1890/1896: 2:409).

40. Veblen 1899/1894, chapters 1,2 , and 9.

41. Veblen 1899/1994, quotations at 15-6.

42. Veblen (1899/1994: 71-2, 79-80, 95).

43. Veblen (1899/1994: 98).

44. Veblen (1914: 47-8). On the foundational character of this ethical principle to classical pragmatism in general and James's thought in particular, see Throntveit 2011, 2014.

45. Veblen (1923: 438-9).

46. Veblen (1914: 15-6, 36).

47. Veblen (1898b: 193-4); Veblen (1914: 36-7).

48. Cordes (2005, esp. 15-6). Particularly important articles explaining, respectively, why prehistorical peoples preferred selfless leaders and egalitarian societies and how the human interest in fairness likely encouraged inequality as societies grew in complexity, are Boehm 1993; Starmans, Sheskin \& Bloom 2017.

49. For seminal works on multi-level selection and major evolutionary transitions, see Lynn Margulis 1971; Smith \& Szathmáry 1999; Okasha 2006. On group selection, see Wilson \& Sober 1989; Wilson \& Wilson 2007; Richerson et al. 2016.

50. Richerson \& Boyd 2005; Wilson 2015; Henrich 2015.

51. Creanza, Kolodny \& Feldman 2017.

52. See Wilson \& Gowdy 2015; Turchin 2016.

53. Wilson 2019.

54. Veblen (1899/1994: 140).

55. Veblen (1898b: 192); Veblen (1914: 25-7).

56. Veblen (1899/1994: 140).

57. Boyte 2004, 2011.

58. Ostrom 1990; Levine (2006: 247).

59. On the Greeks, see Shklar (1991, esp. 68); and Budd 2011, who summarizes the Greek view as: "Free men use things, they do not make them" (22). For Arendt's distinction between private "work" and public "deeds and action" see Arendt (1958: 161-2). Among the most influential arguments that civic identity and skills must be fostered in the voluntary spaces of civil society rather than the remunerative context of work is Barber 1998.

60. On the moral and political thought of James, Dewey, and others influenced by their pragmatist account of the self and society see Throntveit (2014, esp. chapter 5).

61. Boyte (1999: 1-7).

62. See, e.g., Dewey (1916, esp. 140).

63. Veblen (1914: 303, 310); Veblen (1904: 374); Veblen (1919: 178).

64. See especially Bell 1963.

65. Dietz (1994: 874, 876).

66. Veblen (1914: 303-4, 327).

67. Veblen (1914: 303, 310).

68. Boyte 2018; Dzur 2017. 
69. Dzur 2019.

70. See, e.g., Boyte \& Evans 1986; Mathews 2006; Taylor 2012; Peters 2006; Levine 2013.

71. Veblen (1914, esp. chapter 6).

72. Thorstein Veblen, "Christian Morals and the Competitive System" (1902), in Veblen (1934: 200-6, 208-12, 214-6, 218).

73. Veblen (1914: 16-8, 180-1); Veblen (1898b: 192).

74. Veblen (1914: 31-2)

75. See Boyte 1989; Boyte \& Kari 1997.

76. See Born, Lewis \& Straw (2017: 3).

77. A similar belief in the generative rather than merely constraining or distorting role of social phenomena in aesthetic experience is evident in Arnold Berleant's work; see especially Berleant 1997, chapter 9, “The Aesthetics of Community".

78. On this role for aesthetic theory see Pierre Bourdieu 1979/2001; Eagleton 1990.

79. Berleant (1992: 12-3).

80. Born 2010; McMahon 2018.

81. Veblen (1914: 88-9).

82. Veblen (1914: 320).

83. See John Dewey to William James, May 10, 1891 and June 3, 1903, in Perry (1935: 2:517, 520); also Dewey 1909. Dewey had his quibbles over James's conception of truth; see Westbrook (1991: 130-2).

84. Dewey (1934: 45-6).

85. Dewey and Tufts (1908: 276-7; James cited at p. 85).

86. Dewey (1922: 295-300).

87. Dewey (1973: 98).

88. Dewey (1927: 369-72)

89. See, e.g., Veblen 1921, 1923.

90. Veblen's memorandum to the Department of Agriculture was eventually published with an introduction by Joseph Dorfman as Veblen 1932.

91. Veblen (1917: 367).

92. Thorstein Veblen, “Outline of a Policy for the Control of the 'Economic Penetration' of Backward Countries and of Foreign Investments," January 15, 1918, quoted in Throntveit (2017: 266).

93. The centrality of power to Veblen's thought is a major theme of Plotkin \& Tilman 2011. To be fair, Dewey never denied that there were irreconcilable moral commitments and subjective interests, or that social structures affected the outcomes of their clashes; see Rogers 2012. Still, his emphasis on the potential of deliberative discourse to resolve or circumvent conflict often pushed this feature of this thought into the background.

94. On shared power as multiplicative see Mesle 2016; Boyte 2020.

95. On direct interaction's power to build empathy, especially across divides, see Allport 1954; Pettigrew \& Tropp 2006; Hewstone 2015.

96. Veblen (1914: 303, 310, 320-21, 331-4; “pragmatism” at 331n).

97. Becky Veblen Meyers to David Riesman, February 20, 1954, quoted in Throntveit (2008: 546). 


\section{ABSTRACTS}

Few remember Thorstein Veblen (1857-1929) as a connoisseur of beauty or champion of beauty's importance to an institutionally modern and technologically sophisticated society. Similarly few credit Veblen with any constructive theory of politics. Yet Veblen's conception of the beautiful, his account of its role in human cultural evolution, and his critique of its perversion in the industrialized societies of the nineteenth and early twentieth centuries are invaluable to contemporary social-aesthetic aims of political and economic reconstruction. In contrast to the Veblen of memory, the real Veblen devoted significant intellectual energy to building a theory of what political thinkers today call public work: creative, negotiated, open-ended production of shared goods by individuals alert both to self-interest and collective needs. Partaking of the rich tradition of philosophical pragmatism, Veblen's social aesthetics also points to that tradition's continuing value for contemporary aesthetic, social, and political theory. Indeed, further augmented by recent advances in cultural evolutionary theory, Veblen's pragmatist, public-work aesthetics suggests a vision of democratic citizenship defined by cooperative imagination, production, critique, and re-creation of a moral and material commonwealth. The so-called "bard of savagery," therefore, is better understood as a "bard of democracy," narrating the travails and affirming the ideals of a culture aspiring to self-government. His is a vision that might lend the fragmented field of social aesthetics a common, compelling narrative of its own.

\section{AUTHOR}

\section{TRYGVE THRONTVEIT}

Minnesota Humanities Center and Woodrow Wilson International Center for Scholars

throntv[at]gmail.com 